\title{
Preliminary results of parameterisation of DairyMod pasture model for tropical pasture; Brachiaria
}

\author{
$\underline{\text { J.M.P Jayasinghe }}^{\text {a b }(D), \text { Daniel J. Donaghy a }}{ }^{(D)}$, K. G. Pembleton ${ }^{\text {c }}$ (D), David G. Barber ${ }^{\text {d }}$ \\ and T. Ramilan ${ }^{\text {a }}$ iD \\ ${ }^{a}$ School of Agriculture and Environment, Massey University, Private Bag 11 222, Palmerston North 4440, \\ New Zealand \\ ${ }^{b}$ Department of Animal Science, Faculty of Animal Science and Export Agriculture, Uva Wellassa \\ University, Badulla, 90000, Sri Lanka \\ ${ }^{c}$ Centre for Sustainable Agricultural Systems and School of Sciences, University of Southern Queensland, \\ Toowoomba, QLD 4350, Australia \\ ${ }^{d}$ Queensland Department of Agriculture and Fisheries, Gatton Campus, Lawes, QLD 4343, Australia \\ Email:P.Jayasinghe@massey.ac.nz
}

\begin{abstract}
Exploring improved tropical forages is considered to be an important approach in delivering quality and consistent feed options in tropical and even subtropical regions under changing climate scenarios. Pasture modelling has been an effective tool in simulating pasture growth and obviating expensive field research under a range of soil, climate, and management strategies. Many models lack parameters for tropical pasture species, hindering their use in tropical regions. This study aims to adapt the generic parameters in the DairyMod pasture model to parameterise and evaluate the model for the tropical pasture species Brachiaria ruziziensis $x$ B. decumbens $x$ B. brizantha 'Brachiaria Mulato II' (BM). Data were collected from plots of BM established at the Gatton Research Dairy ( $\left.27^{\circ} 54^{\prime} \mathrm{S}, 152^{\circ} 33^{`} \mathrm{E}\right)$, Queensland, Australia from 19 November 2020 to 06 May 2021 to parameterise the model. Model evaluation was performed through various statistical indices for accuracy and precision. Canopy structure and carbon partitioning, photosynthesis and respiration, senescence and leaf appearance parameters were mainly modified from the generic $\mathrm{C}_{4}$ grass parameters in the model. Results showed that, species specific parameters setup for BM in the model simulated the total above ground yield $\left(\mathrm{R}^{2}=0.92\right)$, leaf $\left(\mathrm{R}^{2}=0.97\right)$, and LAI $\left(\mathrm{R}^{2}=0.93\right)$ at a reasonable accuracy. Stem production also ranged under acceptable level except for the second defoliation due to decreased cutting height. Despite these reasonable simulated results, the model tended to underestimate stem production. Reasons could be higher variation of residual weight across the seasons and model failure to explicitly capture the plant physiological changes like anthesis, accelerated growth rate and increased stem production associated with tropical pasture phenological developments. Results suggest that the developed BM parameters in DairyMod need further testing under range of locations and seasons to improve the model.
\end{abstract}

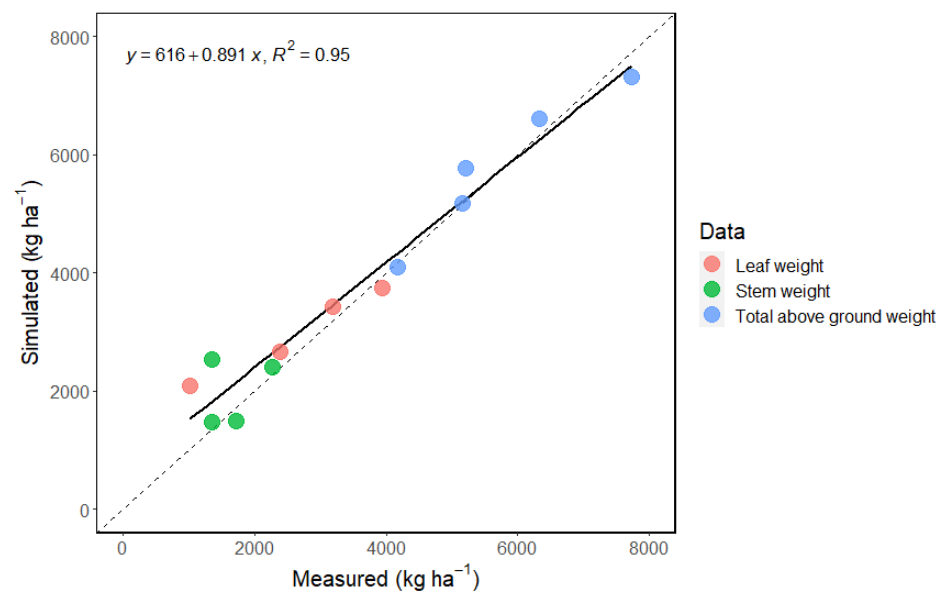

Figure 1. Relationship between measured and DairyMod simulated weights (total above ground, stem, and leaf) of Brachiaria Mulato II in Gatton Research Dairy, Queensland, Australia from December 2020 to May 2021

Keywords: Brachiaria Mulato II, DairyMod, tropical pastures, simulation models 


\section{INTRODUCTION}

Warm-season perennial grasses (tropical grasses/ $\mathrm{C}_{4}$ grasses) are the dominant forages used in tropical and subtropical regions (Cooke et al. 2020). According to the Prentice et al. (1992) that the distribution of $\mathrm{C}_{4}$ grasses are likely to expand into more temperate regions, due to future changes in climate (Sage and Kubien, 2003). Despite the importance of tropical grasses as a livestock feed, the scarcity of consistent quantity and quality forage production is as a major constraint faced by tropical dairy farmers. One of the main approaches to address the feed scarcity and deliver quality feed on a consistent basis has been to develop improved forage options and evaluate for their yield, nutritive value, and impact on animal productivity parameters (Hall et al. 2007 and Ayele et al. 2012). Intensification with improved forages can take two forms as introduction of new forage varieties on-farm to the existing feeding or integrate forage options with new feeding practices in the production system (Paul et al. 2020). However, the choice of appropriate forage species plays a key role in how well the selected species are adapted to the farm environment giving the right balance between quantity and quality (Lowe et al. 2016)

Pasture modelling has been an effective tool in simulating pasture growth and complementing expensive field research by predicting the likely performance of forage species under a range of soil, climate, and management strategies (McCown et al. 2002). There are a number of different simulation models including EcoMod \& DairyMod SGS (Sustainable Grazing Systems), APSIM (Agricultural Production Systems Simulator), GrassGro, DairyNZ Whole Farm Model, and CROPGRO. Despite the importance of pasture modelling in forage-based dairy production, models are infrequently used in the tropics and the greatest limitation is the lack of data and knowledge about the physiological and physical processes of plant growth (Hoogenboom, 2000). According to Andrade et al. (2016), there are a few empirical models to predict the growth and herbage accumulation of genera, Brachiaria, however they are location specific and limit the model extrapolation as they have not considered the underlying physiological principles for a given plant growth. Due to the genotypic dependent physiological behaviours, different pastures carry their optimum growing conditions, responses to water and nutrient requirements. When species-specific physiological processes are well understood, especially for species that are new to a region, they can be synthesized using mechanistic models (Boote et al. 1998) for improving tropical pasture modelling.

Therefore, this study was undertaken to estimate the species-specific parameters required for DairyMod, then calibrate and evaluate these parameters using the field data to successfully predict the growth of the tropical pasture, BM.

\section{DAIRYMOD PASTURE MODEL}

DairyMod is a mechanistic biophysical pasture simulation model (Johnson, 2008). It models pasture growth, utilisation by grazing animals, animal growth and production, soil water, and nutrient dynamics with different pasture management options like irrigation, fertiliser application, and defoliation (including cutting and grazing) management (Johnson, 2008). DairyMod is a dedicated pastoral dairy system model (Li et al. 2011). The model has predicted the growth dynamics of temperate forage species across a range of climates, soil types, and management under conditions in Australia and New Zealand, and outside of Oceania (Argentina, South Africa) but limited applications are reported for predicting growth dynamics for tropical and subtropical pasture species. According to the Johnson (2008), the model has the flexibility to simulate tropical pasture species (DairyMod version 5.8.2 system defaults; generic $\mathrm{C}_{4}$, native $\mathrm{C}_{4}$, native $\mathrm{C}_{4}$ low quality and Rhodes grass) and further Johnson et al. (2003), Johnson et al. (2008), Cullen et al. (2008) and Perera et al. (2020) have shown DairyMod can realistically simulate the $\mathrm{C}_{4}$ pastures (Rhodes grass, native $\mathrm{C}_{4}$ grasses) growth and herbage accumulation under contrasting edapho-climatic and management conditions in subtropical Australia

\section{METHOD}

\subsection{Study location}

This research was conducted at the Gatton Research Dairy $\left(27^{\circ} 54^{\prime} \mathrm{S}, 152^{\circ} 33^{`} \mathrm{E}, 89 \mathrm{~m} \mathrm{msl}\right)$ Queensland, Australia. Climate is characterised as subhumid and subtropical with long hot summers $\left(28-33^{\circ} \mathrm{C}\right)$ and short mild winters $\left(6-10^{\circ} \mathrm{C}\right)$ and an annual average rainfall of $763 \mathrm{~mm}$. Tropical pasture, Brachiaria Mulato II (Brachiaria ruziziensis $x$ B. decumbens $x$ B. brizantha), was established sowing seeds at a rate of $8 \mathrm{kgha}^{-1}$ as 0.1 ha plots in October 2019 using a randomized complete block design, replicated four times. Data collection was carried out from 11 November 2020 to 06 May 2021. 


\section{Climate data}

The climate data (daily rainfall, maximum and minimum temperature, wind speed and humidity) for the experimental period were obtained from the automatic weather station setup at the experimental site. Solar radiation values for the experimental period were acquired through the University of Queensland, Gatton weather station located $0.9 \mathrm{~km}$ from the experimental site.

\section{Soil data}

The soil at the experimental site was characterised as a black vertosols, a self-mulching, seasonally cracking clay soil (clay $>35 \%$ ) (Isbell, 2016). Topography was estimated as nearly flat (slope $<0.5 \%$ ). Soil physical and chemical characteristics for the experimental plots (depth 0-10 and 10-30 cm) were extracted from the analysed field soil samples (cores were sampled on 28 September 2020). Soil profile data collected by Powell (1982) and APSoil database (APSoil ver. 7.20) were used to complete the missing data.

\subsection{Brachiaria Mulato II data}

\section{Biomass data}

Herbage mass were quantified at $28 \pm 2$ days harvesting intervals using quadrat $(0.5 \mathrm{~m} \times 0.5 \mathrm{~m})$ cuts $(n=4)$ clipped to $15 \mathrm{~cm}$ (first cut) and $10 \mathrm{~cm}$ (subsequent cuts) residual height from 19 November 2020 to 06 May 2021. Randomly selected tillers from each plots were evaluated just before every harvest and categorized (vegetative or reproductive) based on the phenological stage of the tiller (seed head presence or not). Harvested herbage samples from each plot were weighed for the fresh weight and subsampled ( $\sim 500 \mathrm{~g})$ for compositional analysis. The residual stubble (tiller base) from the pasture plots was destructively sampled to ground level after each harvesting, to determine the mass and composition. The subsamples of both above harvested and residual stubble were separated into its morphological components (leaf (lamina only), stem (leaf sheath and stem), dead material and flowers) for compositional analysis. Hand dissected components were dried separately at $60^{\circ} \mathrm{C}$ for $48 \mathrm{hrs}$ to determine the dry weight. The dry weights of the subsampled components were used to calculate leaf, stem, dead material, and flower composition of quadrat area $\left(0.25 \mathrm{~m}^{2}\right)$ and subsequently extrapolated to calculate the DM yield $\left(\mathrm{kg} \mathrm{ha}^{-1}\right)$.

Randomly selected subsamples of fresh leaves were scanned for area using the flatbed scanner and analysed using the ImageJ software (Easlon and Bloom, 2014). Leaves were dried separately at $60^{\circ} \mathrm{C}$ for 48 hrs to determine the dry weight to calculate the specific lead area (SLA) of each sample. Subsequently, total dry weights of the leaf fraction harvested inside the quadrat area of each sample were used to calculate the total leaf area index (LAI).

After each harvesting, plots were mulched to $10 \mathrm{~cm}$ residual height to achieve equal re-growing conditions. All plots were irrigated during the experimental period using hand shift irrigation allowing pastures to grow under non limiting water conditions. Fertiliser CK77 (13.3\% nitrogen $(\mathrm{N}), \quad 2.2 \%$ phosphorus $(\mathrm{P}), 13.5 \%$ potassium (K), 19.6\% sulfur (S ) was applied on 23 November 2020 before starting the measurements at a rate of $40 \mathrm{~N}, 6.6 \mathrm{P}, 40.5 \mathrm{~K}$, and $58.8 \mathrm{~S} \mathrm{~kg} \mathrm{ha}^{-1}$. Urea $(46 \% \mathrm{~N})$ and CK77 were applied on 18 January 2021 and 19 February 2021 at a rate of $69 \mathrm{~N} \mathrm{~kg} \mathrm{ha}^{-1}$ and $26 \mathrm{~N}, 4.4 \mathrm{P}, 27 \mathrm{~K}$ and $39.2 \mathrm{~S} \mathrm{~kg} \mathrm{ha}^{-1}$ respectively. Plots were sprayed with Titan450 (2,4-D, Isopropylamine) for weeds (Johnson grass) at a rate of $2 \mathrm{~kg} \mathrm{ha}^{-1}$ on 11 December 2020 and 7 January 2021.

\section{Canopy light interception}

The spatial average of PAR (Photosynthetically Active Radiation) was measured immediately before each harvest using MQ-301 light meter (Apogee Instruments, Inc, USA). In each plot, 2 readings of incoming PAR $\left(\mathrm{PAR}_{\mathrm{i}}\right)$ above the canopy level and 8 readings of transmitted PAR $\left(\mathrm{PAR}_{\mathrm{t}}\right)$ at ground level (placing the quantum sensor bar closer to the soil between the clumps) were taken. Measured canopy PARs were used to calculate the fraction of PAR intercepted (LI) by the canopy and subsequently the light extinction coefficient $(k)$.

\section{Leaf photosynthesis}

The rate of net photosynthesis was measured on 11 February 2021 and 12 February 2021 at pre-harvest stage with a portable photosynthesis meter, model LI-6400XT with brad leaf chamber and LED light source (LICOR Biosciences, USA). All the readings were taken representing the middle portion of the youngest fully expanded leaves. Using pre-set auto programs leaf net photosynthesis was recorded once per plot $(n=4)$ at a series of PAR levels $\left(2000,1500,1000,500,250,120,60,30,15,0 \mathrm{PPF}_{\mu} \mathrm{mol}^{-1} \mathrm{~mol}^{-1} \mathrm{~m}^{-2}\right)$ with a reference $\mathrm{CO}_{2}$ concentration of $400 \mathrm{ppm}$. Similarly, net photosynthesis of leaves in two plots $(n=2)$ were measured under range 
of $\mathrm{CO}_{2}$ concentrations $(50,100,200,300,400,700,800,1200,1500,1700 \mathrm{ppm})$ at a reference light condition of $1000 \mathrm{PPF}^{\mathrm{mmol}} \mathrm{m} \mathrm{mol}^{-1} \mathrm{~m}^{-2}$. All photosynthesis measurements were taken at $30^{\circ} \mathrm{C}$ leaf temperature inside the chamber (reflective of the ambient temperature at the trial site). Measured data were used to parameterise the light and $\mathrm{CO}_{2}$ response curves in DairyMod leaf photosynthesis sub-module.

\subsection{Model parameterisation}

Generic $\mathrm{C}_{4}$ parameters in DairyMod version 5.8.2 was used as the starting point and modifications were undertaken following the directions of Hunt and Boote (1998) and Johnson (2008). Brachiaria Mulato II species specific parameters were derived from the experimental data and relationships reported in literature (mainly temperature, senescence, and $\mathrm{N}$ partitioning parameters). Experimental conditions (mulching, $\mathrm{N}$ fertilisation, irrigation) during the data collection period were included in the Management submodule. Soil characteristics were defined in the soil module and soil initial conditions were adjusted based on the soil data and local weather conditions. All simulations were carried out in 1 ha paddock at an average of $3.078 \mathrm{t} \mathrm{ha-1}$ residual weight (measured average residual weight). Simulations were carried out with soil carbon and $\mathrm{N}$ dynamic implemented.

\subsection{Model evaluation}

Simulated total biomass, leaf weight, stem weight, LAI were compared with observed values to evaluate model performance. The model was evaluated for the accuracy and precision. Observed/simulated ratio, mean observed and simulated, liner regression between observed and simulated data $\left(\mathrm{R}^{2}\right)$, root mean square error (RMSE), were considered as the statistical indices. All analysis were performed in R statistical computing software (R version 4.0.5) using the package 'Metrics' (Hamner and Frasco, 2018).

\section{RESULTS AND DISCUSSION}

\subsection{DairyMod parameterisation}

\section{Leaf and canopy photosynthesis}

The model was parameterised using the data collected from an irrigated experiment assuming the plants were growing under no limiting water and $\mathrm{N}$ conditions, which allowed the calibration for "ideal" conditions. Canopy photosynthesis and respiration lie as the core of the pasture sub-model and acts as the main primary source of carbon. The pasture sub-model describes the leaf gross photosynthesis as a function of PAR ( $\mu$ mol $\mathrm{CO}_{2} \mathrm{~m}^{-2}$ leaf ${ }^{-1} \mathrm{~s}^{-1}$ ), leaf $\mathrm{N}$, temperature, and $\mathrm{CO}_{2}$. Species-specific photosynthesis light response and respiration parameters $\left(\mathrm{CO}_{2}\right.$ for BM were estimated using the non-rectangular hyperbola described by (Johnson, 2008) (Figure 1). The rate of single leaf gross photosynthesis at saturating PAR $\left(\mathrm{P}_{\max }\right)$ was estimated to be $28.95 \pm 0.98$ $\mu \mathrm{mol} \mathrm{CO} \mathrm{Cm}^{-2} \mathrm{~s}^{-1}$ and respiration at reference conditions was $2.41 \pm 0.33 \mu \mathrm{mol} \mathrm{CO} \mathrm{m}^{-2} \mathrm{~s}^{-1}$. Photosynthetic response to $\mathrm{CO}_{2}$ at saturating $\mathrm{CO}_{2}$ and at double ambient $\mathrm{CO}_{2}$ were estimated to be $1.17 \pm 0.015$ and $1.10 \pm 0.015$ (unitless) respectively.

Temperature response to the $\mathrm{P}_{\max }$ is defined in the model with two temperature variables, minimum and optimum temperature at ambient $\mathrm{CO}_{2}$. Default values $\left(12^{\circ} \mathrm{C}\right.$ and $\left.35^{\circ} \mathrm{C}\right)$ were modified to $15^{\circ} \mathrm{C}$ and $33^{\circ} \mathrm{C}$ based on the results reported by Pequeno (2014) and Moreno (2017) for BM. The leaf N concentration effect on the photosynthesis was kept as default for $\mathrm{C}_{4}$ grasses with 3 and $4 \mathrm{~N} \%$ for optimum and maximum leaf $\mathrm{N}$ respectively (Moreno, 2017). Light interception and attenuation by the canopy in the model are explained by the $\mathrm{k}$ and the value was set to 0.48 based on the measured light LI data and Moreno (2017) also reported similar $\mathrm{k}$ value (0.49) for BM.

\section{Canopy structure and carbon partitioning}

Measured biomass data excluding the reproductive phases were used to calculate the canopy structure and carbon partitioning in the model. Specific leaf area and number of live leaves per tiller were set to $22 \mathrm{~m}^{2} \mathrm{~kg}^{-1} \mathrm{DM}$ and4 respectively based the measured data Plart senescence parameters vere adjusted based on the values repated by Pequeno (2014) and Moreno (2017) for Brachiaria species assuming values do not significantly vary between cultivars within the same species. Leaf appearance and temperature response explain in the model using three parameters (minimum leaf appearance interval, minimum temperature for leaf appearance, and temperature for maximum leaf appearance rate). These values were not measured during this study and adopted from Pequeno (2014), Moreno (2017) and Bosi et al. (2020) studies related to Brachiaria. 


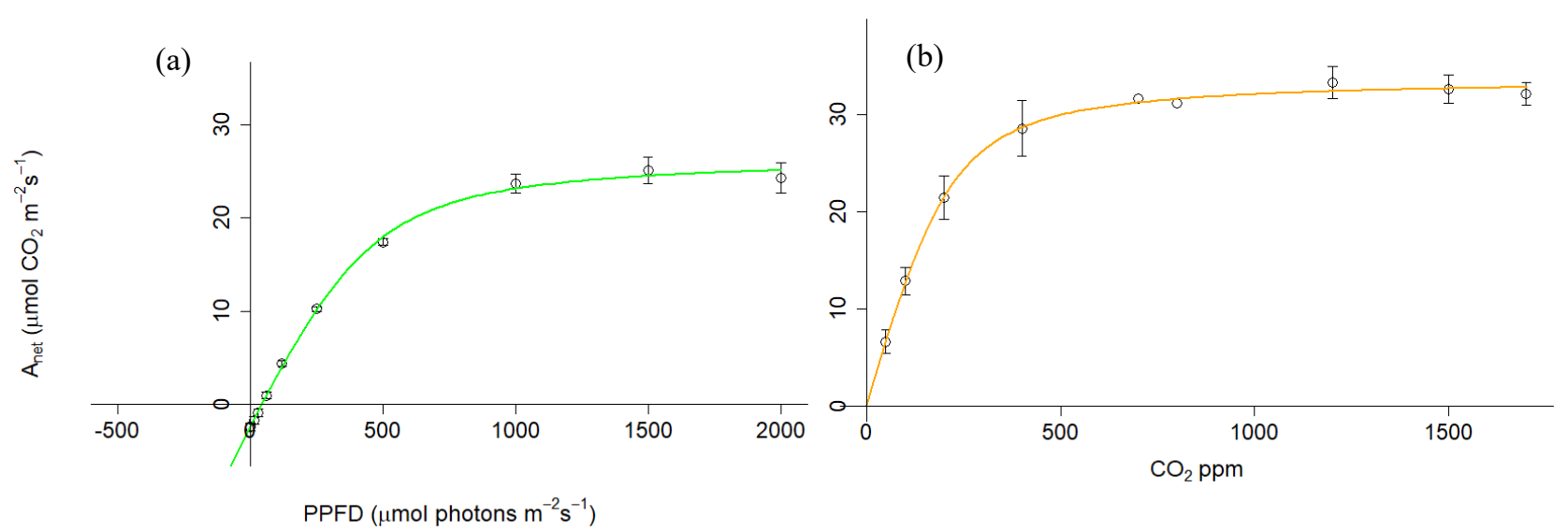

Figure 2. Species-specific photosynthetic light response (a) and $\mathrm{CO}_{2}$ response curve (b) of Brachiaria Mulato II fitted by non-rectangular hyperbola function for the estimation of leaf photosynthetic parameters $\left(\mathrm{A}_{\text {net }}\right.$; Net carbon assimilation $\mu \mathrm{mol} \mathrm{CO} \mathrm{Cm}^{-2} \mathrm{~s}^{-1}$, PPFD; Photons flux density $\mu \mathrm{mol}$ photons $\mathrm{m}^{-2} \mathrm{~s}^{-1}$ ).

\section{Low temperature stress}

Tropical pastures are reported to have considerably low growth rates during the cooler months of the year due to the low temperature stress (McWilliam, 1978; Ivory and Whiteman,1978). This result was observed in this study, during late April to early May (late autumn). DairyMod explains the low temperature stress by 'full stress' and 'initial stress' temperatures. Therefore, default values $\left(3^{\circ} \mathrm{C}\right.$ and $\left.7^{\circ} \mathrm{C}\right)$ for tropical pastures were modified to $5^{\circ} \mathrm{C}$ and $11^{\circ} \mathrm{C}$ based on measured biomass accumulation data in last season (late autumn).

\subsection{Model evaluation}

Parameterised DairyMod pasture model for Brachiaria Mulato II simulated total yield, leaf, stem, and LAI with reasonable accuracy (Table 1 and Figure 2). Total above ground biomass was predicted with greater accuracy than the leaf and stem yield. However, it is evident that stem productions was poorly predicted in the model and it had largely underestimated values compared to measured data.

Table 1. Summary of the statistics for the simulations of Brachiaria Mulato II calibration dataset collected from Gatton Research Dairy, Queensland, Australia from December 2020 to May 2021(total weight, leaf, and stem weight are expressed in DM, LAI; Leaf area index, $n$; number of observations)

\begin{tabular}{lllll}
\hline Statistical indices & $\begin{array}{l}\text { Total Weight } \\
\left(\mathrm{kg} \mathrm{ha}^{-1}\right)\end{array}$ & $\begin{array}{l}\text { Leaf Weight } \\
\left(\mathrm{kg} \mathrm{ha}^{-1}\right)\end{array}$ & $\begin{array}{l}\text { Stem Weight } \\
\left(\mathrm{kg} \mathrm{ha}^{-1}\right)\end{array}$ & $\begin{array}{l}\text { LAI } \\
\left(\mathrm{m}^{2} \mathrm{~m}^{-2}\right)\end{array}$ \\
\hline Observed mean & 5718.30 & 2629.93 & 1665.45 & 6.20 \\
Simulated mean & 5791.64 & 2984.73 & 1970.57 & 6.57 \\
Obs/Sim & 0.90 & 0.92 & 0.53 & 1.05 \\
RMSE & 341.13 & 577.14 & 608.04 & 1.11 \\
$\mathrm{R}^{2}$ & 0.92 & 0.97 & 0.08 & 0.93 \\
$n$ & 5 & 4 & 4 & 4 \\
\hline
\end{tabular}

The variability of stem accumulation in Figure 2 (c) and lower $\mathrm{R}^{2}$ is explained due to the changed cutting height $(15 \mathrm{~cm}$ to $10 \mathrm{~cm})$. However, overall poor stem simulation in the model could be due to the variation of residual weights in the paddocks wherein the model only accommodated an average residual weight across all harvestings. In addition to the residual variation, the model does not capture the plant phenological development and failed to explicitly simulate the phenological changes (Cullen et al. 2008) (anthesis, accelerated growth rate and increased carbon partitioning to stem) especially during the reproductive phase. 

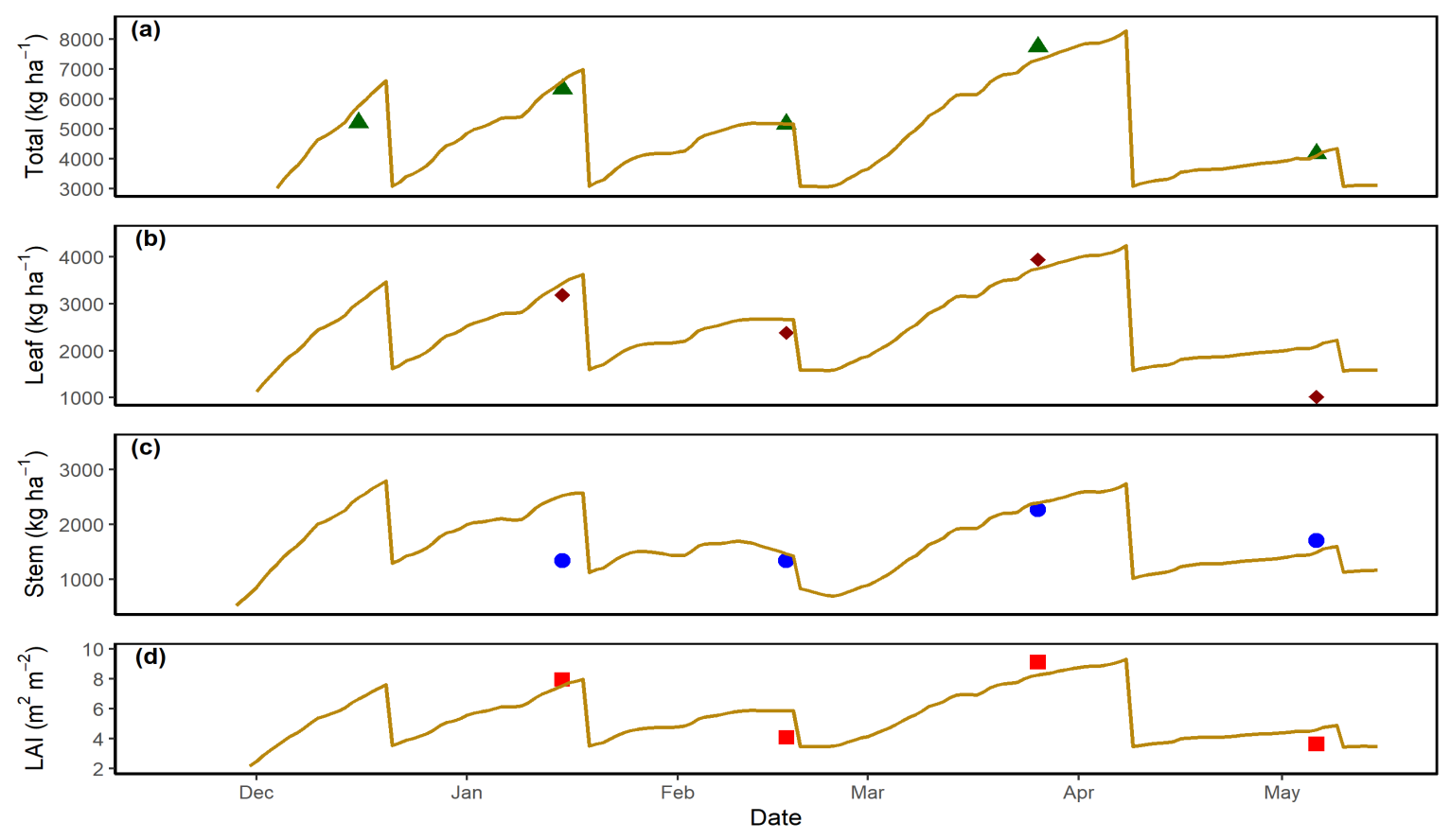

Figure 3. DairyMod simulated (lines) and (a) observed total above ground yield (triangles), (b) leaf yield (diamonds), (c) stem yield (circles), (d) Leaf area index (LAI) (squares) of Brachiaria Mulato II in Gatton Research Dairy, Queensland, Australia from December 2020 to May 2021.

\section{CONCLUSION}

Simulation results revealed default $\mathrm{C}_{4}$ generic parameters can be successfully used as a starting point for setting up new tropical pastures in DairyMod. Parameterised pasture model for BM predicted the total above ground biomass and leaf yield at each harvesting point with a reasonable accuracy $\left(\mathrm{R}^{2=} 0.92\right.$ and 0.97$)$. Despite these reasonable simulated results, the model tended to underestimate stem production, indicating further work is required in the area of tropical pasture stem partitioning in the model using additional stem and leaf data. These improvements will provide better simulations of tropical pasture phonological changes.

Results of the present study gives important insights on tropical pasture model parameterisation and model use under cutting management, however testing under grazing is required to improve the model to be able use in tropical pasture grazing system. Additional data collection and validation of the model under different edaphoclimatic and management conditions are also required to further test the model, so that the model can be applied in simulating seasonal production, recommending to a set of environmental conditions and evaluate likely performances under climate change scenarios.

\section{Acknowledgments}

This study is a collaboration between Massey University, Palmerston North, New Zealand and Gatton Research Dairy, Gatton, Queensland, Australia. The authors of the study would like to thank all the supportive staff at Gatton Research Dairy for their effort in data collection and tropical pasture plots management. The authors would like to specially extend gratitude to Marcelo Benvenutti, Research Scientist and Anthony Cootes, Technical Officer for their technical support.

\section{REFERENCES}

Andrade, A. S., Santos, P. M., Pezzopane, J. R. M., de Araujo, L. C., Pedreira, B. C., Pedreira, C. G. S., Marin, F. R., and Lara, M. A. S., 2016. Simulating tropical forage growth and biomass accumulation: an overview of model development and application. Grass and Forage Science, 71(1), 54-65.

Ayele, S., Duncan, A., Larbi, A., and Khanh, T. T., 2012. Enhancing innovation in livestock value chains through networks: Lessons from fodder innovation case studies in developing countries. Science and Public Policy, 39(3), 333-346.

Boote, K.J., Jones, J.W., Hoogenboom, G. and Pick Ering, N.B.,1998. The CROPGRO model for grain legumes. In: Tsuji G.Y. (ed.) Understanding options for agricultural production, pp. 99-128. Dordrecht, Netherlands: Kluwer Academic. 
Bosi, C., Sentelhas, P. C., Huth, N. I., Pezzopane, J. R. M., Andreucci, M. P., and Santos, P. M., 2020. APSIMTropical Pasture: A model for simulating perennial tropical grass growth and its parameterisation for palisade grass (Brachiaria brizantha). Agricultural Systems, 184, 102917.

Cooke, R. F., Daigle, C. L., Moriel, P., Smith, S. B., Tedeschi, L. O., and Vendramini, J. M. B., 2020. Cattle adapted to tropical and subtropical environments: social, nutritional, and carcass quality considerations. Journal of Animal Science, 98(2).

Cullen, B. R., Eckard, R. J., Callow, M. N., Johnson, I. R., Chapman, D. F., Rawnsley, R. P., Garcia, S. C., White, T., and Snow, V. O., 2008. Simulating pasture growth rates in Australian and New Zealand grazing systems. Australian Journal of Agricultural Research, 59(8), 761-768.

Easlon, H. M., Bloom, A. J., 2014. Easy Leaf Area: Automated digital image analysis for rapid and accurate measurement of leaf area. Applications in Plant Sciences, 2(7), 1400033.

Isbell, R., 2016. The Australian Soil Classification. $2^{\text {nd }}$ edition . CSIRO Publishing, Australia.

Ivory, D., and Whiteman, P., 1978. Effect of temperature on growth of five subtropical grasses. I. Effect of day and night temperature on growth and morphological development. Functional Plant Biology, 5(2), 131-148.

Hall, A., Sulaiman, R., Bezkorowajnyj, P., 2007. Reframing technical change: livestock fodder scarcity revisited as innovation capacity scarcity. A Conceptual Framework. ILRI, ICRISAT, IITA, UNUMERIT.

Hamner, B. and Frasco, M., 2018. Metrics: Evaluation Metrics for Machine Learning. R package version 0.1.4. https://CRAN.R-project.org/package=Metrics.

Hoogenboom G., 2000. Contribution of agrometeorology to the simulation of crop production and its applications. Agricultural and Forest Meteorology, 103, 137-157.

Hunt, L. A., Boote, K. J., 1998. Data for model operation, calibration, and evaluation. In G. Y. Tsuji, G. Hoogenboom, \& P. K. Thornton (Eds.), Understanding Options for Agricultural Production (9-39). Springer Netherlands.

Johnson, I. R., Chapman, D., Parsons, A., Eckard, R., and Fulkerson, W., 2003. DairyMod: a biophysical simulation model of the Australian dairy system. $1^{\text {st }}$ Australian Farming Systems Conference, Toowoomba, Queensland, Australia.

Johnson, I.R., 2008. Biophysical pasture model documentation: model documentation for DairyMod. EcoMod and the SGS Pasture Model. IMJ Consultants: Armidale, NSW) Available at www. imj. com. au/gmdocs [Verified 14 March 2008].

Johnson, I.R, Chapman, D., Snow, V., Eckard, R., Parsons, A., Lambert, M., and Cullen, B. 2008. DairyMod and EcoMod: biophysical pasture-simulation models for Australia and New Zealand. Australian journal of experimental agriculture, 48(5), 621-631.

Li, F. Y., Snow, V. O., and Holzworth, D. P., 2011. Modelling the seasonal and geographical pattern of pasture production in New Zealand. New Zealand Journal of Agricultural Research, 54(4), 331-352.

Lowe, K. F., Hume, D. E., and Fulkerson, W. J., 2016. Perennial Forage and Pasture Crops - Species and Varieties. In Reference Module in Food Science. Elsevier.

McCown, R.L., 2002. Locating agricultural decision support systems in the troubled past and socio-technical complexity of 'models for management'. Agricultural Systems, 74(1), 11-25.

McWilliam, J.R., 1978. Response of pasture plants to temperature. In: Wilson, J.R. (Ed.), Plant Relations in Pastures. CSIRO, East Melbourne, pp. 17-34.

Moreno, L. S., 2017. Modelling Regrowth Dynamics of Two Contrasting Forage Grasses in Response to Shade and Nitrogen Fertilization. Ph.D. thesis, University of Florida, USA.

Paul, B. K., Koge, J., Maass, B. L., Notenbaert, A., Peters, M., Groot, J. C. J., and Tittonell, P., 2020. Tropical forage technologies can deliver multiple benefits in Sub-Saharan Africa. A meta-analysis. Agronomy for Sustainable Development, 40(4), 22.

Pequeno, D. N. L., 2014. Agronomic performance and adaptation of the CROPGRO - Perennial Forage Model to predict growth of three tropical forage grasses under irrigated and rainfed conditions. Ph.D. thesis, University of São Paulo, Brazil.

Perera, R. S., Cullen, B. R., and Eckard, R. J., 2020. Changing patterns of pasture production in south-eastern Australia from 1960 to 2015. Crop and Pasture Science, 71(1), 70-81.

Powell, B, 1982. Soils of the Gatton Research Station. Queensland Department of Primary Industries.

Prentice, I. C., Cramer, W., Harrison, S. P., Leemans, R., Monserud, R. A., \& Solomon, A. M.,1992. Special Paper: A Global Biome Model Based on Plant Physiology and Dominance, Soil Properties and Climate. Journal of Biogeography, 19(2), 117-134.

Sage, R.F., Kubien, D.S., 2003. An ecophysiological perspective on global change and the future of $\mathrm{C}_{4}$ plants. Photosynth. Res. 77, 209-225. 